\title{
Analysis of sesame seed production and export trends; challenges and strategies towards increasing production in Uganda
}

\author{
Cosmas Wacal ${ }^{1, *}$, Daniel Basalirwa ${ }^{2}$, Walter Okello-Anyanga ${ }^{3}$, Marius Flarian Murongo ${ }^{1}$, \\ Caroline Namirembe ${ }^{4}$ and Richard Malingumu ${ }^{5}$ \\ ${ }^{1}$ Faculty of Agriculture, Uganda Martyrs University, P.O. Box 5498, Kampala, Uganda \\ 2 The United Graduate School of Agricultural Sciences, Tottori University, 4-101 Koyama-Minami, Tottori 680-8553, Japan \\ ${ }^{3}$ National Semi-Arid Resources Research Institute (NaSARRI), P.O. Box 56, Soroti, Uganda \\ ${ }^{4}$ Graduate School of Sustainability Science, Tottori University, 4-101 Koyama-Minami, Tottori 680-8553, Japan \\ 5 Muni University, P.O. Box 725, Arua, Uganda
}

Received 29 July 2020 - Accepted 13 December 2016

\begin{abstract}
Sesame (Sesamum indicum L.) is one of the most ancient oilseed crops cultivated for its edible oil and uses in food. Sesame seeds are very nutritious and confer health benefits. However, its potential production in Uganda has not been fully realized. The objective of this review was to summarize the trends in sesame production, export quantity, export value, challenges, and strategies for sustainable sesame seed production in Uganda. The review revealed the sesame seed production and area harvested generally increased from 1996 to 2007 but significantly decreased between 2008 and 2018. The review also revealed that while the export quantities and values were low, they gradually increased from 2009 to 2016 . The decreased production between 2008 and 2016 could have been due to challenges such as pests and diseases, loss of soil fertility, prolonged drought, poor agronomic practices, poor yielding varieties, and lack of access to credit. Therefore, it is recommended to improve breeding programs and soil management practices; strengthen agricultural credits and extension services to support marketing of sesame seeds; and improve agronomic practices and farmer knowledge on improved techniques such as sowing methods, plant spacing, intercropping practices, pests and disease control measures. These could boost sesame production in Uganda given the high domestic and global demand for sesame seeds and provide an opportunity to expand sesame production throughout Uganda. Research should focus on how to increase seed yield on farmers' fields and bridge the yield gap between researchers and farmers while adopting good agronomic practices.
\end{abstract}

Keywords: Sesamum indicum L. / production trends / export market / seed yield / production challenges / agronomic practices

Résumé - Analyse des tendances de production et d'exportation de graines de sésame; défis et
stratégies pour augmenter la production en Ouganda. Le sésame (Sesamum indicum L.) est l'une des
plus anciennes graines oléagineuses cultivées pour son huile comestible et ses utilisations dans
l'alimentation. Les graines de sésame sont très nutritives et confèrent des bienfaits pour la santé. Cependant,
son potentiel de production en Ouganda n'a pas été pleinement exploité. L'objectif de cette étude était de
résumer les tendances de la production de sésame, la quantité et la valeur des exportations, les défis et les
stratégies pour une production durable de graines de sésame en Ouganda. L'étude a révélé que la production
de graines de sésame et la superficie récoltée ont généralement augmenté entre 1996 et 2007 , mais ont
considérablement diminué entre 2008 et 2018 . L'étude a également révélé que si les quantités et les valeurs
des exportations étaient faibles, elles ont progressivement augmenté de 2009 à 2016 . La baisse de la
production entre 2008 et 2016 pourrait être due à des problèmes tels que les ravageurs et les maladies, la
perte de fertilité des sols, la sécheresse prolongée, les mauvaises pratiques agronomiques, les variétés à
faible rendement et le manque d'accès au crédit. Il est donc recommandé d'améliorer les programmes de

*Correspondence: cwacal@gmail.com 
sélection et les pratiques de gestion des sols ; de renforcer les crédits agricoles et les services de conseil pour soutenir la commercialisation des graines de sésame; et d'améliorer les pratiques agronomiques et les connaissances des agriculteurs sur les techniques améliorées telles que les méthodes de semis, l'espacement des plants, les pratiques de cultures intercalaires, les mesures de lutte contre les parasites et les maladies. Ces mesures pourraient stimuler la production de sésame en Ouganda, compte tenu de la forte demande intérieure et mondiale de graines de sésame, et offrir la possibilité d'étendre la production de sésame à tout le pays. La recherche devrait se concentrer sur la manière d'augmenter le rendement des semences dans les champs des agriculteurs et de combler l'écart de rendement entre les chercheurs et les agriculteurs tout en adoptant de bonnes pratiques agronomiques.

Mots clés : Sesamum indicum L. / tendances de la production / marché d'exportation / rendement des semences / défis de la production / pratiques agronomiques

\section{Introduction}

Sesame (Sesamum indicum L.) is a diploid $2 n=26$ plant belonging to the family of Pedaliaceae and it is one of the most ancient oilseed crop cultivated worldwide for its versatile food uses especially the edible oil and uses in food (Ashri, 1989). There are numerous wild relatives of sesame species that occur in Africa and with a smaller number in India (Sani et al., 2014). Uganda has the following wild species: Sesamum angolense and Sesamum angustifolium, which are used for vegetables and medicinal purposes (Bedigian, 2010). Although the origin of sesame remains controversial, most accept sesame was first domesticated in India as evidenced by morphological and cytological affinities that exist between the domesticated sesame and the South Indian species Sesamum malabaricum (Bedigian, 2003a, 2003b). Currently, sesame is cultivated in several regions of the world including Uganda, and it is adapted to both subtropical and tropical climates.

Sesame seeds are very nutritious and therefore confer health benefits. The seeds contain a very high oil content (32.8-62.7\%) nominally about 52-55\% (Uzun et al., 2008; Wei et al., 2015, Couch et al., 2017). Sesame oil contains a high unsaturated essential fatty acids content [linoleic acid (37-47\%), oleic acid (35-43\%)] and low saturated fatty acid content [palmitic acid (8-11\%) and stearic acid (5-10\%)], the seeds also contain $14.1-29.5 \%$ proteins, $4.3-20.5 \%$ carbohydrates, 4.2-6.9\% ash, and 2.7-6.7 fiber content, along with vitamin E, minerals, lignans (sesamolin and sesamin), and tocopherols (Fukuda et al., 1985; Kamal-Eldin et al., 1992; Unal and Yalcin, 2008; Hassan, 2012, Couch et al., 2017). The monounsaturated fatty acids such as oleic and polyunsaturated fatty acids such as linoleic acids are the two most important and predominant fatty acids in sesame seeds (Anilakumar et al., 2010; Zahran et al., 2020). In addition, sesame seed mineral composition includes K (349-851 mg/100g), P (50$890 \mathrm{mg} / 100 \mathrm{~g}), \mathrm{Mg}(305-79 \mathrm{mg} / 100 \mathrm{~g}), \mathrm{Ca}(80-1263 \mathrm{mg} / 100 \mathrm{~g})$ and sodium (123 mg/100g) (Nzikou et al., 2009; Couch et al., 2017). The high nutritional contents in sesame seeds includes a high amount of anti-oxidant substances (lignan contents) such as sesamin, sesamolin, which makes it consumed as a health food (Wu, 2007). In addition, sesame oil is very resistant to oxidative deterioration due to tocopherols whose bioavailability can be increased by sesamol, which can only be found in sesame seeds making it a very special oil crop (Wu, 2007). These functional ingredients in sesame protect against hypertension, hypercholesterolemia, cancers, and for managing atherosclerosis, diabetes mellitus, obesity, chronic renal failure, rheumatoid arthritis, Alzheimer's disease as well as dermatological diseases (Kanu et al., 2010; Nagendra Prasad et al., 2012).

In Uganda, sesame is second oilseed crop after groundnuts, and over $80 \%$ of the crop is cultivated in the Northern and Eastern parts of the country where it plays an important role in the local diet (Anyanga and Obong, 2001; Ssekabembe, 2007). The seeds can be processed to paste, oils, and is used in confectionary and medicinal ingredients. In Uganda, sesame is mostly produced by smallholder farmers that contribute to the country's export of sesame seeds. Sesame has been grown since 1910 and is well adopted in the farming communities of Uganda (Rubaihayo and Anyanga, 1997). Sesame is considered a cash crop and is currently given attention as a priority crop. However, its potential production has not been fully realized as a result of several challenges that have affected its production and trade in Uganda in the past decades. Therefore, the primary objective of this review is to summarize the trends of sesame production, export quantity and export value over two decades (1996-2018) and providing insights in to the opportunities, challenges, and future research in sesame in Uganda. This review could provide guidance for farmers and researchers on how to increase sesame production in Uganda with the goal of being one of the leading sesame seed producers in the world sesame trade.

\section{Methods}

In this review, secondary data were obtained from Food and Agriculture Organization of the United Nations' (FAO) statistical databases. The FAO's data of sesame seed production, seed yield, area harvested, export quantity and export values from sesame in Uganda was obtained for the period 19962018 (22 years) (FAOSTAT, 2018). Furthermore, a correlation analysis was conducted using SPSS version 22.0, released 2013 (SPSS for windows Inc., Chicago, IL, USA) to reveal the relationship between the production, seed yield, area harvested, export quantity and export value. We also performed a detailed review of literature from credible sources to document the challenges facing sesame production in Uganda, recommendations, the opportunities and research work required in the future to increase sesame seeds production as described systematically in the following section. 


\section{Overview, trends of sesame seed production, area harvested, seed yield, export quantity and export values in Uganda}

\subsection{Overview of world sesame seed production and trade in 2018}

Worldwide, in 2018, sesame was cultivated on an estimated area of about 11.7 million hectares with Sudan, India, Myanmar, United Republic of Tanzania and South Sudan contributing 29.6, 14.7, 12.5, 6.8 and 5.3\% of the world total area harvested of sesame (FAOSTAT, 2018). Uganda had $1.8 \%$ of the total world area harvested of sesame (11.7 million hectares) in 2018 (FAOSTAT, 2018). According to FAOSTAT, the top 5 world sesame seed producers were Sudan (981 000 tons), Myanmar (768 858 tons), India (746 000 tons), Nigeria (572761 tons) and United Republic of Tanzania (561 103 tons) (Fig. 1). Uganda ranked the 11th sesame seed producer in the world with 140000 tons in 2018, making it the 8th largest sesame seed producer in Africa.

FAOSTAT, shows that the main sesame seeds importers in the world include China, mainland (828211 tons), Japan (157 170 tons), Turkey (152237 tons), Republic of Korea (72 063 tons), and Viet Nam (63 761 tons). Uganda exports most of its sesame to these countries. In 2018 with 21192 tons, Uganda ranked the 13th largest exporter of sesame seeds in the world and the 9th in Africa. Sudan (451 177 tons) was the largest exporter followed by India (326828 tons) as shown in Figure 2.

\subsection{Uganda sesame seed production and area harvested between 1996 and 2018}

According to FAOSTAT, in the period 2000-2007, Uganda ranked the 5th largest sesame seed producer, but declined to the 7 th in 2008-2009, 8th in 2010 and 10th in 2012. This showed that production of sesame seeds in Uganda was gradually decreasing and probably facing competition from other producers although it was still in the 11th position in 2018 contributing $2.3 \%$ of world total sesame seed production. The analysis of trends showed that the production of sesame seeds was initially at 73000 tons in 1996 which did not significantly change in 1997 and 1998 but increased to 93000 tons in 1999 . By 2007, the production of sesame seeds had reached 168000 tons, with peak production occurring between 2005 and 2007 (Fig. 3). However, this increase ceased, and seed production decreased to 99000 tons in 2008. Thereafter, it fluctuated reaching the maximum in 2011 and 2014 with seed production above 140000 tons. The results showed an increasing trend in sesame production in Uganda in the last two decades. Overall, the changes showed that in the period 1996-2000, seed production increased by $24.7 \%$ but this could not be sustained and the period 2004-2008 showed decrease by $26.3 \%$ compared with 2004 . Furthermore, there was a decrease in production in the period 2012-2016. The production of sesame seed in 2017 and 2018 were 146, 000 tons and 140, 000 respectively representing an increase by $47.9 \%$ in 2018 compared with 1996.

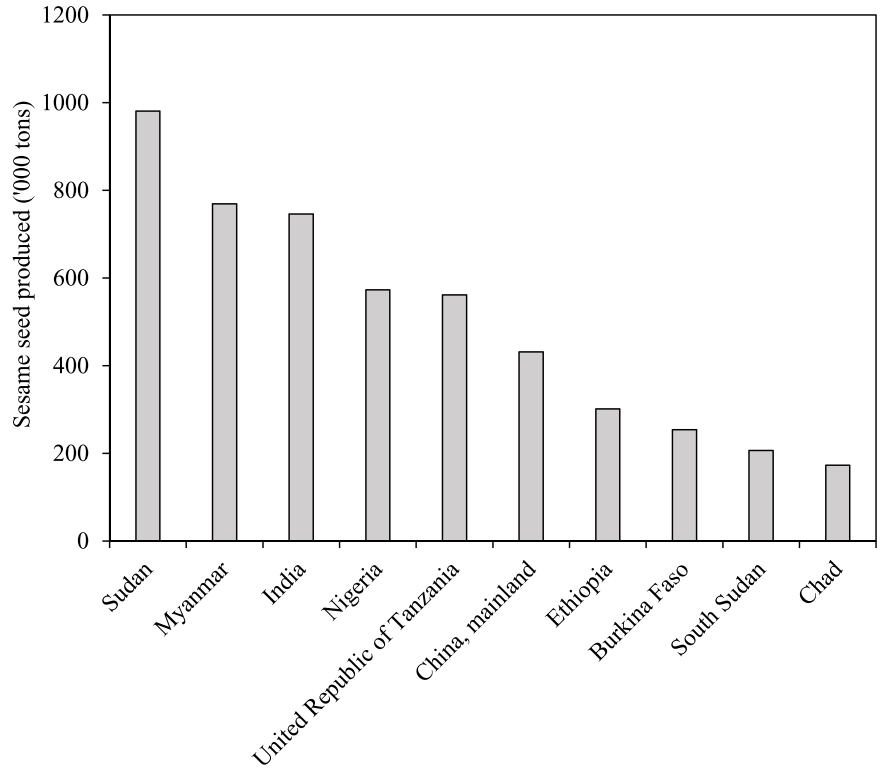

Fig. 1. Top 10 sesame producing countries in the world in 2018.

The area harvested under sesame cultivation significantly increased from 172000 ha in 1996 to 280000 ha in 2007 (Fig. 3). The peak area harvested of sesame showed a peak between 2003 and 2007, but there was a drastic decline in the area harvested in 2008 (165000 tons), until 2011 when acreage increased above 200000 ha. The area harvested significantly increased from 1996 until 2008 where a drastic decline by $4.2 \%$ compared with that in 1996 occurred. The major decrease in the area harvested occurred in 2008 , decreasing by $54.6 \%$ compared with 2004 . The area under production increased by $14 \%$ in 2009 compared with 2008 (165000 ha) and remained more or less the same through 2018. The area under sesame production remained more or less the same between 2011 (202752 ha) and 2018 (210000 ha) although an increase by $1.4 \%$ in 2018 compared to 2016 occurred. The overall trend showed an increase in area under sesame cultivation between 1996 and 2007, followed by a drastic decline in 2008 and an increase in 2009 that was stable through 2018.

\subsection{Uganda sesame seed yield between 1996 and 2018}

The sesame seed yield was lowest between 1996 and 1998 (424-430 kg ha ${ }^{-1}$ ) but gradually increased to $\sim 500 \mathrm{~kg} \mathrm{ha}^{-1}$ by 1999 (Fig. 4). From 2005, the seed yield increased to $\sim 600 \mathrm{~kg} \mathrm{ha}^{-1}$, remaining constant up to 2010 and increased to $\sim 700 \mathrm{~kg} \mathrm{ha}^{-1}$ in 2011 and 2014 . Overall, on average the seed yield $\left(557 \mathrm{~kg} \mathrm{ha}^{-1}\right)$ was above the world seed yield, and the trend suggested great improvement in the seed yields of sesame in Uganda. The average seed yield of sesame worldwide is about $578 \mathrm{~kg} \mathrm{ha}^{-1}$, while in Uganda the sesame yield on average is $619 \mathrm{~kg} \mathrm{ha}^{-1}$ well above the world's average (FAOSTAT, 2018). The results also show that high seed yield $\left(\sim 700 \mathrm{~kg} \mathrm{ha}^{-1}\right)$ in Uganda was attained in 2011, 2014 and 2017. However, the seed yield in 2018 became lower by $4.7 \%$ compared to $2017\left(667 \mathrm{~kg} \mathrm{ha}^{-1}\right)$. Over the past two decades and beyond (1996-2018), the average sesame seed yield has 


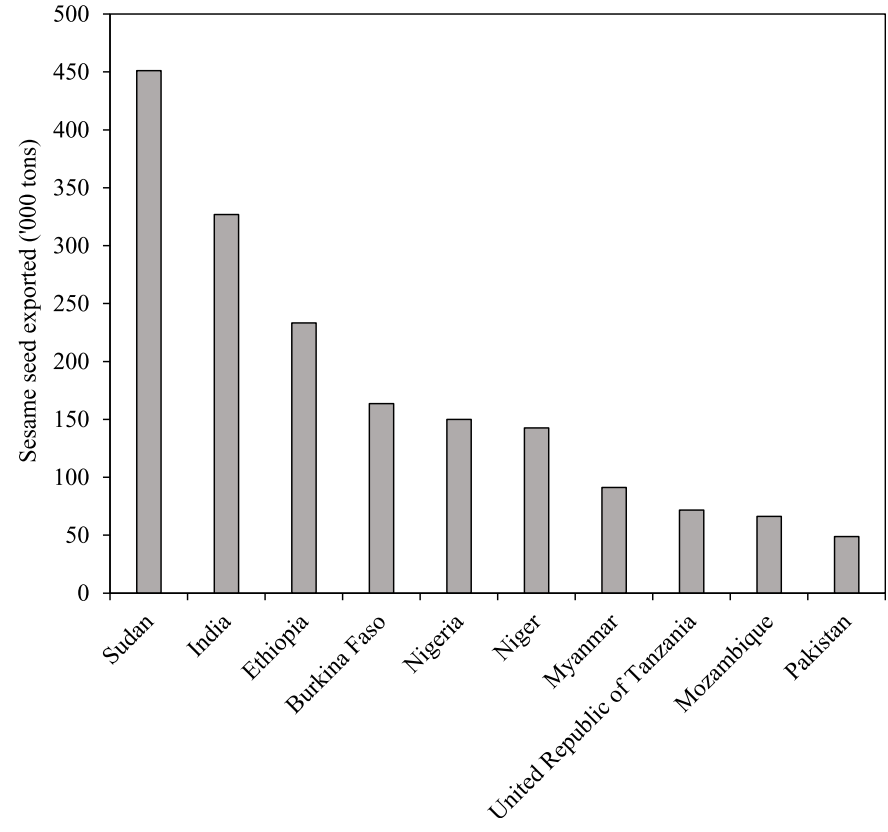

Fig. 2. Top 10 sesame exporters in the world in 2018 .

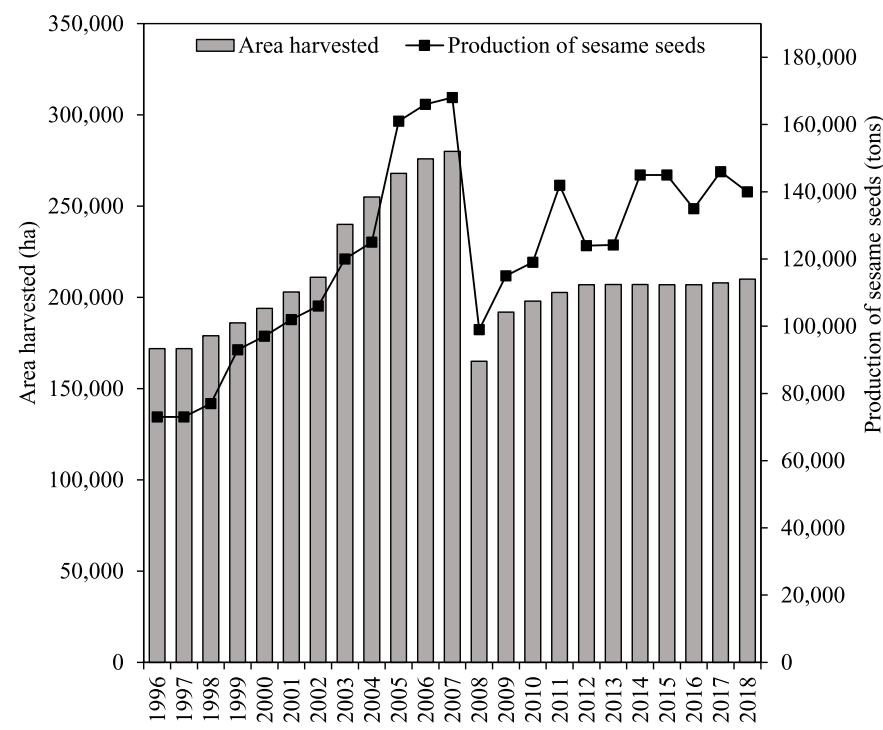

Fig. 3. Trends in sesame production and area harvested in Uganda between 1996 and 2018.

been $568 \mathrm{kgha}^{-1}$ in Uganda which was above the world average $\left(490 \mathrm{~kg} \mathrm{ha}^{-1}\right)$ during the same period.

\subsection{Uganda sesame export quantity (tons) and export values (USD) between 1996 and 2018}

Initially, the export quantity was high in 1996 (12 117 tons) but significantly decreased from 1997 to 43 tons in 1998 (Fig. 5). However, a sharp recovery occurred in 1999 (2325 tons) and remained below 2000 tons between 2000 and 2003. From 2004, the seed export quantity increased above 4000 tons with an annual increasing trend up to

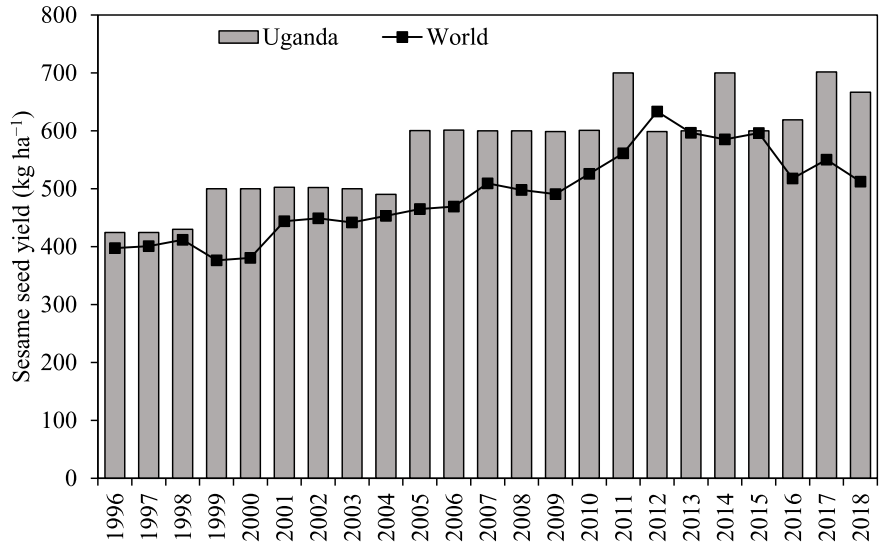

Fig. 4. Trends in sesame seed yield in the world and Uganda between 1996 and 2018.

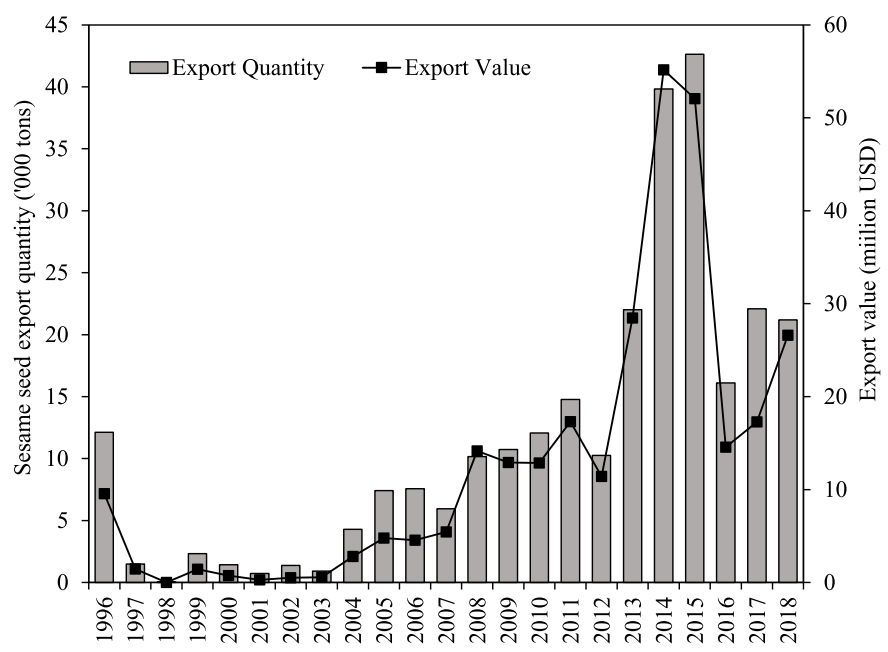

Fig. 5. Trends in Uganda's sesame seed export quantity and values between 1996 and 2018.

42631 tons in 2015. However, there was a drastic decline in the export quantity in 2016(16113 tons) compared to 2015, without any significant changes in 2017(22092 tons) and 2018 (21 192 tons). Although a slight decline occurred in 2016 to 2018 , the overall trend showed increase in the export of sesame seeds from 2008 to 2018 .

Similar to the export quantity, export values were initially high in 1996 earning Uganda 9563000 USD but significantly decreased from 1997 (1 448000 USD) to 1998 (11 000 USD). However, increase in the export earning occurred in 1999(1420000 USD) and the following years showed significantly low earning up to 2003 (573000 USD). From 2005 , the export value (earnings) were above 4000000 USD, and this increased annually up to 55165000 USD in 2014. However, in 2016, a significant decrease in the export earnings occurred (14 563000 USD) indicating decrease in the quantity exported and the decreased sales of sesame. The export values in 2017 (17287000 USD) and 2018 (26 614000 USD) remained lower than the maximum value attained in 2014. Overall, the export quantity decreased in the periods 
Table 1. Correlation analysis between export, yield, area harvested and production of sesame seeds in Uganda from 1996 to 2018.

\begin{tabular}{|c|c|c|c|c|c|c|}
\hline & Export quantity & Export value & Uganda yield & World yield & Area harvested & $\begin{array}{l}\text { Production of } \\
\text { sesame seeds }\end{array}$ \\
\hline \multicolumn{7}{|l|}{ Export quantity } \\
\hline Uganda yield & $0.655^{* *}$ & $0.619 * *$ & & & & \\
\hline World yield & $0.730^{* *}$ & $0.718^{* *}$ & $0.782 * *$ & & & \\
\hline
\end{tabular}

*: Correlation is significant at the 0.05 level (2-tailed); **: Correlation is significant at the 0.01 level (2-tailed).

1996-2000 and 2008-2012 indicating low sales of sesame seeds to the international markets. Similarly, the export values decreased by a greater value in the period 1996-2000 indicating a great loss in export earnings (8.81 million USD lost) and in 2008-2012, it decreased by $23.9 \%$. The increase in the export quantity in the period 2008-2018 showed that there was high demand of sesame and market information could have been available to farmers and sesame traders hence the exported most of the sesame produced.

\subsection{Correlation analysis between the overall export quantity, export values, seed yields, area harvested, and production of sesame seeds}

The correlation analysis showed that the export quantity and values were significantly and positively correlated with the seed yield indicating that increased export was due to high seed yields in Uganda (Tab. 1). Furthermore, the area harvested showed significant positive correlation with production of sesame seeds indicating that an increase or decrease in area harvested resulted in a similar trend in the sesame seeds produced. The production of sesame seeds showed a significant positive correlation with export quantity but without a significant correlation with export value. This indicated that production was triggered by international demand for sesame seeds allowing Uganda earn foreign revenue. Furthermore, production of sesame seeds showed a significant positive correlation with both seed yield of Uganda and world indicating production was dependent on attainable yield.

\section{Challenges and strategies for increasing production in Uganda}

\subsection{Challenges}

\subsubsection{Diseases and pests}

The results showed area harvested and sesame seed production significantly decreased between 2008 and 2018 basically due to several challenges in sesame production. One of the major production problem is pests and diseases. Sesame is prone to diseases and pests which cause significant yield losses. Several diseases such as Cercospora leafspots affect sesame yields in Uganda. The decreasing seed production is also attributed to insect pests such as gall midge (Asphondylia sesami) and webworm (Antigastra catalaunalis), which have been noted to significantly reduce sesame seed yields. In the Northern part of Uganda, a total of 38 insect pest species were infesting sesame. Sesame webworm and sesame gall midge were noted as the major pests contributing to $62 \%$ and $98.8 \%$ of pest occurrences, respectively (Egonyu et al., 2005). This indicates that sesame yield could have been significantly decreased by pest damage rendering less harvestable seeds. For instance, the sesame webworm is responsible for estimated $90 \%$ of yield losses due to pests in Uganda (Egonyu et al., 2005; Ssekabembe et al., 2006). In addition, there are postharvest pests, which decrease sesame seeds quality during storage. The sesame seed bug (Elasmolomus sordidus) is a post-harvest pest that attacks the capsules and damages seeds during drying and storage by reducing the oil content (Elamin et al., 2015).

\subsubsection{Soil fertility decline}

The loss of soil fertility due to continuous cropping has significantly affected yields of major crops in Uganda including sesame. Soil nutrients have been depleted as a result of farmers not adding inorganic fertilizers or other sources of nutrients in each cropping season. The soils in Uganda have lost fertility, and the declining soil fertility levels have been indicated by decrease in the soil organic carbon content (Musinguzi et al., 2015). The smallholder farmers cannot afford inorganic fertilizers and so little of nitrogen $(\mathrm{N})$, phosphorus $(\mathrm{P})$ and potassium $(\mathrm{K})$ are added in the soil, and there is little use of organic materials. This implies that low yields could be due to poor soils with limited NPK, which are important for sesame. The growing areas suffer continuous cropping without proper fertilizer addition (Nakyagaba et al., 2005). Recently, sesame yield has been reported to decrease with the increase in continuous cropping due to nutrient depletion especially available $\mathrm{N}$ (Wacal et al., 2019a). The poor seed yields from less fertile soil directly contribute to low seed production.

\subsubsection{Climate change and drought}

Climate change accompanied by prolonged drought and unpredictable rainfall is one of the main global factors affecting agriculture with negative effects on oilseed crops. The rainfall patterns in Uganda have drastically fallen and has also affected the yields of other major crops besides sesame. Although sesame is considered a drought tolerant crop, it is sensitive to drought especially at the vegetative stage and its 
potential production is limited by drought stress in the semiarid regions (Boureima et al., 2011, 2012). Most smallholder farmers that grow sesame practice rainfed agriculture in the Northern and the Eastern parts of the country which is characterized by drought periods. Usually, sesame is produced in two seasons per year. The first season of sesame is planted in March and harvested between June and July while the second season crop is planted in August and harvested around December (Munyua et al., 2013). However, both the rainfall onset and cessation has become unpredictable affecting timely planting of sesame. The rainfall distribution is often nonuniform, characterized by weeks of lack of rain (moisture) during the growing periods of sesame. This non-uniform distribution of rainfall during the crop growing season and inadequate water supply has not only affected sesame production in Uganda but other crops as well (Epule et al., 2018). In addition, the growing season of sesame may be interrupted by early cessation of rain resulting into low sesame yields especially of the local varieties that have long maturity days. Therefore, adoption and cultivation of improved early maturity cultivars are important to increase sesame yields in Uganda.

\subsubsection{Poor agronomic practices}

The poor agronomic practices by farmers such as late planting, broadcasting, lack of weeding, and lack of adoption of knowledge could have decreased sesame production between 1997 and 2004 as shown by the data (Fig. 3) since sesame yields well under good management. Although FAOSTAT showed average yields of $619 \mathrm{~kg} \mathrm{ha}^{-1}$, seed yield of sesame in Uganda is still far below the potential seed yield of $2000 \mathrm{~kg} \mathrm{ha}^{-1}$ in sesame (Brigham, 1985). Nakyagaba et al. (2005) reported that the low sesame seed yield in Uganda are partly due to improper agronomic practices that include inappropriate fertilizer levels, poor planting methods involving broadcasting, and untimely weed management. For instance, lack of weed control can result in low seed yield. The weeds compete with sesame for water, light and nutrients. However, when controlled at early stage of sesame growth, yield is not affected. This is because weeds can be dangerous for sesame at seedling stages but after sesame has formed a canopy, it tolerates and outcompetes weeds, which does not result in to high yield losses (Langham, 2008).

\subsubsection{Low yielding varieties}

Poor yielding farmers' varieties could be another reason for poor production between 1997 and 2003. These traditional varieties are characterized by low yield, late maturity and lack resistance to pests and diseases. During the period from 1991 to 2000 , the seed yield of sesame had been very low between 107 to $773 \mathrm{~kg} \mathrm{ha}^{-1}$ in Uganda (Anyanga et al., 2003). The low yielding varieties from farmers could not meet the world sesame standard and perhaps varietal mixture of seeds rendered low quality thereby affecting the export. However, the rise in the production of sesame from 2005 onwards could indicate that high yielding varieties which are drought tolerant, resistant to pests and diseases could have been adopted by sesame farmers in Uganda. The sesame yield in Uganda were increased only after the year 2005 and this was attributed to adoption of new high yielding varieties released by the researchers (Fig. 4). Furthermore, this is also evidenced by the decreased area harvested as compared to the increased sesame seed production in 2011 and 2014 (Fig. 3). Seed yield per unit area was increased instead of land area.

\subsubsection{Lack of access to affordable credit services}

The low sesame production and yield are due to smallholder not being able to access and afford credit to implement farming activities. Credit is important for paying wages, hiring equipment, preparing land, and purchasing seeds and fertilizers. This affects the timely implementation of agricultural farm operations. This has hindered most farmers from performing farming activities in time, thereby resulting in to poor yields and low production. For instance, the challenges of sesame production include lack of equipment to prepare land leading to late planting and inadequate labor for planting in rows, weeding and harvesting (Munyua et al., 2013). If credit facilities to provide working capital and pay labor was available, these challenges would have been addressed to increase seed production.

\subsubsection{Poorly established sesame markets}

Market related challenges could have affected sesame seed trade in this study. The Figure 5 showed low export quantity and export values obtained between 1997 and 2018. Although sesame seed production was high, low export and export values were obtained, which could have been caused by market related challenges. These could be due to lack of market information to farmers and sesame seed traders. Several farmers could have had the sesame seeds but sold at low prices due to price fluctuation in sesame as well as other commodities. For instance, there has also been periods where sesame prices are low due to shortage of demand which has discouraged a number of sesame farmers. In addition, the falling Ugandan shilling against the dollar has negatively affected the export of foreign exchange since sesame seed exporters have to pay more to export. There is also lack of market information and numerous middlemen in the sesame value chain which hinders direct sales of sesame seeds to major exporters (Munyua et al., 2013; Dalipagic and Elepu, 2014). Munyua et al. (2013) furthermore mentions that Uganda experiences a high road transport cost to the nearest ports such as Mombasa as compared to shipping costs to China and other markets since it is a land locked county without a sea port. These could have affected the seed export. This implies that the amount of sesame seeds reaching the international markets was also low. Other factors such as infrastructure could have affected transportation and marketing of sesame seeds from the farmers to the markets possibly resulting to low export especially in the period 1997-2003. Especially during the years of insurgency in the Northern Uganda in the early 1990s and before 2001, the construction of road networks could have been affected, and sesame could not be easily transported to main exporters. However, since peace and stability in the Northern and Eastern region was restored, the production slightly increased from 2004 onwards possibly due to access to markets and improved infrastructure. 


\subsubsection{Little research}

Despite the importance of sesame, it has received little research both in Uganda and globally since the crop was considered as an orphan crop (under exploited species) with less support from science, industry and policy makers (Ssekabembe, 2007; Dossa et al., 2017). Thus, there is still little information generated on genetic improvement, and adoption of good agronomic practices that increase seed yield and quality of sesame. This could have affected productivity of sesame in Uganda between the periods 1996-2002, and 20082018.

\subsubsection{Limited land allocated to sesame under subsistence farming}

With the increase in Uganda's population, arable land is expected to become limited as a result of creation of new urban areas. A report by UBOS (2016) shows that Uganda's population was estimated at 34.6 million projected to be growing at an annual rate of $3 \%$ and is projected to reach 41.2 million by 2020 (UBOS, 2014). These have resulted in to land fragmentation allowing fewer large pieces of land allocated for farming. Although this is not a major problem in agriculture, food crops such as maize, cassava, beans among others have been allocated more land than other minor crops such as sesame. According to Munyua et al. (2013), sesame in Uganda is usually cultivated in two seasons per year but in Northern Uganda, it is grown mainly in the second rains. Land under other major food crops has increased while that under sesame has decreased, and this is affecting Uganda's sesame seed production. Moreover, the agricultural system associated with small scale subsistence farming practices could be negatively affect sesame production. Subsistence farming is common in most African countries, and it is characterized by the production of farm produce that is used to supply family food. The surplus is sold unlike specialized commercial farmers producing primarily to supply the markets (Sibhatu and Qaim, 2017; AGRA, 2017). Over $80 \%$ of farms in Africa (including Uganda) are smaller than 2 ha in size (Lowder et al., 2016). In Uganda, sesame crop is usually produced by subsistence farmers (Munyua et al., 2013), and the quantity produced under such small scale subsistence farming is not sufficient to satisfy the international demand.

\subsubsection{Summary of challenges}

Overall, a combination of challenges ranging from agronomic to socioeconomic factors are influencing sesame production and trade in Uganda (Fig. 6). These factors interact and affect the overall production of sesame seeds and therefore it is important to address these challenges in order to improve sesame production.

\subsection{Strategies to address challenges}

\subsubsection{Improvement in the breeding programs}

One of the keys is breeding cultivars that are resistant to biotic stress such as diseases, and pests that cause tremendous seed yield losses. Sesame breeding is the mandate of the National Semi-Arid Resources Research Institute which is responsible for the development of new varieties such as Sesim 1,2 and 3 using participatory varietal selection by farmers. Sesame varieties in Uganda include both local land races and improved sesame varieties such as Sesim 1 and Sesim 2 that have been bred for commercial production (Anyanga et al., 2003). However, it is still necessary to breed drought tolerant and adaptable cultivars to cope with the rapidly changing climatic conditions. Climate change leading to shortage of rain and drought contributes to significant yield decline not only in sesame but also in major crops grown in Uganda. Increasing breeding capacity by establishing more sesame research centers across the country to expand sesame cultivation and adoption in Uganda could be another alternative. Generation of improved seeds and ensuring that seeds of newly released sesame varieties are easily accessed by farmers at affordable prices through the seed companies should be emphasized. Management of Cercospora leaf spot, gall midge and webworm could be managed through breeding resistant varieties, crop rotation, and use of pesticides could help (AfrII, 2017). Recently, breeding work on sesame in Uganda has resulted in to genotypes that are environmentally stable with high yield, resistant to pests and possessing high oil. As a result, a new sesame variety Sesim 3 was released in 2013 for commercial production (Anyanga et al., 2016). Studies are also being conducted on sesame genotypes with resistance to sesame webworm in Uganda (Matina et al., 2016). Breeding sesame for pest resistance is one of the effective ways as a control measure against pests and is believed to be efficient and much easier to implement than other control measures for the smallholder farmers with limited resources (Bayoumi and ElBramawy, 2007). Therefore, it is important to breed sesame varieties that are high yielding to increase production since high yield will increase quantity of seed produced.

\subsubsection{Soil nutrient management to improve soil fertility}

Farmers should adopt soil nutrient management to prevent soil exhaustion resulting from nutrient mining. Due to the declining soil fertility, the government has subsidized the prices of fertilizer in Uganda to improve crop production. Therefore, there is need to increase fertilizer use so as to increase sesame yields. Unfortunately, there is still lack of information on the effect of inorganic fertilizers on sesame growth and yield as well as nutrition in Uganda. However, several inorganic fertilizers such as NPK have shown tremendous results in sesame in other countries (Shehu et al., 2009; Haruna, 2011). In a field experiment, it was found that phosphorus applied at varying rates from 0 up to $120 \mathrm{~kg} \mathrm{ha}^{-1} \mathrm{P}$ gave optimal yield at $92 \mathrm{~kg} \mathrm{ha}^{-1} \mathrm{P}$ in Bangladesh (Mian et al., 2011). Furthermore, the application of $60 \mathrm{~kg}$ $\mathrm{ha}^{-1} \mathrm{~N}$, and $13.2 \mathrm{~kg} \mathrm{ha}^{-1} \mathrm{P}$ showed high yields in Samara, Nigeria (Haruna and Aliyu, 2012). Other forms of inorganic fertilizers such as bio-fertilizer sprays together with $76 \mathrm{~kg}$ of $\mathrm{P}_{2} \mathrm{O}_{5} \mathrm{~kg} \mathrm{ha}^{-1}$ increased productivity of sesame on sandy reclaimed soils (Hafiz and El-Bramawy, 2012). It was also found out that interaction of $70 \mathrm{~kg} \mathrm{ha}^{-1}$ of $\mathrm{N}$ and $50 \mathrm{~kg} \mathrm{ha}^{-1}$ of $\mathrm{P}$ gave high economic benefits due to high sesame yield (Kashani et al., 2015). Furthermore, research reported that apparent $\mathrm{N}$ recovery and $\mathrm{P}$ were highest when $75 \mathrm{~kg} \mathrm{ha}^{-1}$ of N and $22.5 \mathrm{~kg} \mathrm{ha}^{-1}$ of $\mathrm{P}_{2} \mathrm{O}_{5}$ were applied to sesame which also increased dry matter and yield of sesame (Shehu, 2014). 


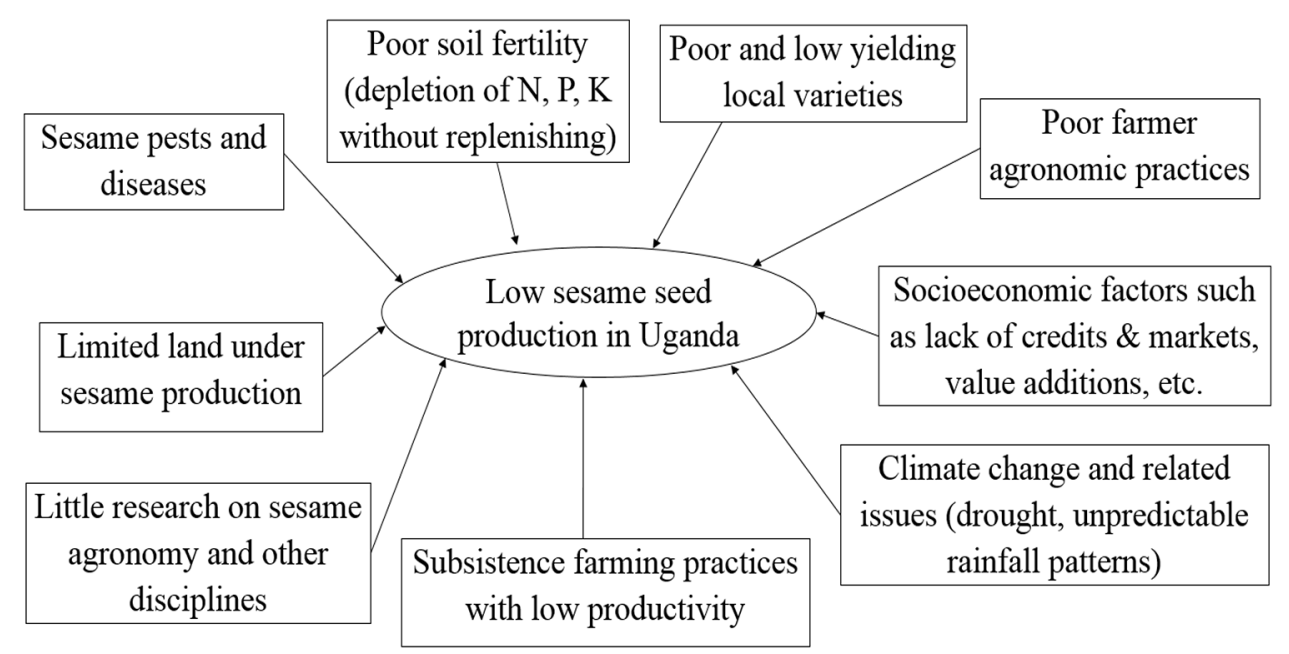

Fig. 6. Summary of production and socioeconomic factors influencing sesame seed production and trade in Uganda.

In addition to NPK, sulphur (S) fertilizer has beneficial effects on yield and quality of oilseed crops including sesame (Scherer, 2001; Jadav et al., 2010; Raza et al., 2018). For instance, Paul et al. (2019) studied the effect of sulphur rates 0 , $10,20,30,40$ and $50 \mathrm{~kg} \mathrm{Sha}^{-1}$ on the seed yield and oil content of sesame in Bangladesh and results showed that the highest seed yield $\left(800 \mathrm{~kg} \mathrm{ha}^{-1}\right)$ and oil content $(44 \%)$ were obtained with $30 \mathrm{~kg} \mathrm{~S} \mathrm{ha}^{-1}$. This was attributed to the stimulation of metabolic energy of the sesame plant, which enhanced the number of seeds per pod and increase in oil content due to higher oil synthesis at the $30 \mathrm{~kg} \mathrm{~S} \mathrm{ha}^{-1}$ application rate. Raza et al. (2018) also reported positive effects of sulphur fertilization on sesame yield and quality upon comparing different rates of $20,30,40$ and $50 \mathrm{~kg} \mathrm{~S} \mathrm{ha}^{-1}$ applied at sowing time and reported improved seed yield at $40 \mathrm{~kg} \mathrm{~S} \mathrm{ha}^{-1}$ due to the considerable increase in number of capsules per plant, seeds per capsule and seed weight. The authors attributed this to the availability and enhanced efficient utilization of soil N, P and $\mathrm{K}$ as these nutrients increased with sulphur application in sesame. Thus, $\mathrm{S}$ is a vital nutrient that has to be applied in combination with $\mathrm{N}, \mathrm{P}$ and $\mathrm{K}$ to enhance sesame yield and quality.

In applying inorganic fertilizers, care should be taken to ensure the appropriate timing and method of application is observed. $\mathrm{P}$ and $\mathrm{K}$ fertilizers can be applied as full doses at sowing whereas half (first dose) of $\mathrm{N}$ is applied at sowing and the other half (second dose) at flower initiation since sesame uses $\mathrm{N}$ primarily during flowering stage (Mian et al., 2011; Gebrelibanos, 2015;Kashani et al., 2015). Applying N in split method is intended to avoid losses through leaching, denitrification and volatilization from the mobile form of $\mathrm{N}$ fertilizer such as urea (Zenawi and Mizan, 2019). According to Zenawi and Mizan, the second dose of $\mathrm{N}$ fertilizer can be applied through side-dressing placed at $3-5 \mathrm{~cm}$ deeper in the soil next to sesame plant to maximize nitrogen use efficiency. To ensure high fertilizer use efficiency, the timing of fertilizer application should coincide with adequate soil moisture since plants absorb soil nutrients dissolved in the water (Langham, 2020). Langham also recommends that considering the economic benefits of fertilizer application before use for sesame production since too much application of N, P, K and S could reduce yield and waste resources.

Farmers should be encouraged to use soil amendments that replenish nutrients to increases sesame yields. It has been recommended to use crop residues in sesame fields to increase crop yields. Unfortunately, many smallholder farmers in Uganda cut sesame plants and gather them in shocks or on a raised drying racks and upon threshing, the straws are not returned to the field. This could be attributed to limited knowledge and awareness that crop residues are source of nutrients up on decomposition in the soil. This practice leads to nutrient mining and thus soil fertility decline. It is reported that in a crop with $1000 \mathrm{~kg} \mathrm{ha}^{-1}$ of seed, the stover contains $60 \mathrm{~kg} \mathrm{~N}, 11 \mathrm{~kg} \mathrm{P}, 94 \mathrm{~kg} \mathrm{~K}$, and $6 \mathrm{~kg} \mathrm{~S}$; the leaves contain $16 \mathrm{~kg} \mathrm{~N}, 2 \mathrm{~kg} \mathrm{P}, 18 \mathrm{~kg} \mathrm{~K}$, and $2 \mathrm{~kg} \mathrm{~S}$; the seeds contain $39 \mathrm{~kg} \mathrm{~N}$, $7 \mathrm{~kg} \mathrm{P}, 4 \mathrm{~kg} \mathrm{~K}$, and $3 \mathrm{~kg} \mathrm{~S}$. The nutrient content of the leaves remain in the field as well as the stover below the lowest capsule. The nutrient content of the seed is lost to the field. A major portion of the stover nutrients are removed from the field and not returned after threshing out the seed (Langham, 2020). With continuous removal of these sesame residues from the field, declining soil fertility evidenced by low total $\mathrm{C}$ and $\mathrm{N}$ results leading to low sesame yield (Wacal et al., 2019b). Thus, incorporation of sesame residues after harvesting and threshing is recommended to replenish the nutrients lost through crop harvest. Other crop residues such as finger millet husks could also release nutrients and provide adequate soil nutrients such as $\mathrm{N}$ and $\mathrm{P}$ for improving sesame growth (Anguria et al., 2017a). In addition, manures from poultry, cattle and other sources could be applied in sesame fields. Other research shows that sesame responds well to manure addition and a combination of both manure with inorganic fertilizers in other African countries (Ogbonna and Umar-Shaba, 2012; Haruna and Abimiku, 2012a; Gore et al., 2016). For instance, a combination of poultry manure at $5 \mathrm{tha}^{-1}$ with $60 \mathrm{~kg} \mathrm{ha}^{-1} \mathrm{~N}$ and $13.2 \mathrm{kgha}^{-1} \mathrm{P}$ has been reported to produce optimal sesame yield with appreciable level of economic returns in Nigeria (Haruna and Aliyu, 2012b). Moreover, the application of organic manure alone is cheaper to small holder farmers compared to expensive inorganic fertilizers. These organic 
manures can easily improve the soil physical and chemical properties of poor soils in Uganda.

Furthermore, sesame yields could be increased through application of biochar materials. Biochar is a by-product of pyrolysis of organic materials in limited oxygen. Several raw materials can be used as feed stocks to make biochar such as wood chips, organic wastes, plant residues and poultry manure (Sohi et al., 2010). Biochar can be produced from readily available crop residues such as rice husks, coffee husks, maize residues, and sorghum and millet residues and animal dung. These residues could easily be converted to biochar to avoid waste accumulation and help sequester carbon while increasing crop yields. In Uganda, there is little or no extensive use of biochar in sesame cultivation. However, in countries such as Nigeria and Japan, biochar application in sesame has significantly improved sesame yield (Ndor et al., 2015; Wacal et al., 2019b). Ndor et al. (2015) reported that in a sesame cultivation on a highly leached ultisols with low base saturation and strongly acidic soils, rice husk biochar at $10 \mathrm{tha}^{-1}$ significantly improved soil physical properties such as bulk density, porosity, chemical properties of increased $\mathrm{pH}$ (for acidic soil), total N, K, Mg and CEC. Biochar has the potential to increase the fertility of poor soils in Africa including Uganda and could boost sesame production. Unfortunately, there are still research gaps on biochar use in sesame in Uganda.

\subsubsection{Improvement in agricultural credits and extension}

It is recommended to increase access and affordability of quick loans to sesame farmers and organizations of sesame cooperatives to ensure each sesame farmer benefits from sesame cultivation. Credit facilities, like the banks and village saving groups, giving out loans to support farming of sesame should provide cheap interest rates using available farmer collaterals. The extension services provided by both the government and private organizations participating in livelihood programs should be strengthened to increase awareness on improved farming techniques in sesame farming and adoption of good innovative technologies simple to adapt to the local conditions to improve sesame production.

\subsubsection{Improvement in agronomic practices and farmer knowledge}

Improvement in agronomic practices such as adoption of proper plant spacing together with adequate nutrient supply are important. Properly spaced sesame plants could increase yield as opposed to the popular broadcasting methods used by smallholder farmers which usually results in close spacing. When sesame is closely spaced, competition for nutrients, light and water results and weeding becomes difficult as the case with other major crops. The recommended spacing in Uganda is $30 \times 10 \mathrm{~cm}$ or $30 \times 15 \mathrm{~cm}$ depending on soil fertility (Umar et al., 2020). Unfortunately, this is not well adopted by farmers. Therefore, the farmers need to be informed on the benefits of spacing sesame through strengthening the agricultural extension system. To avoid diseases and pests, farmers are encouraged to practice crop rotation such as sorghum, peanuts, soybeans, sunflower and other vegetables (Langham, 2008; Munyua et al., 2013). In terms of farm operations, it is known that sesame production is labor intensive requiring manpower in land preparation, planting, weeding and harvesting. To improve on labor in sesame production, introduction of manual sowing tools can reduce seed costs. Improving germination of planting seeds should be encouraged. Sesame seed planters, ox-ploughs and weeders could be introduced for sesame production as low-cost technologies. Furthermore, pests and diseases could be controlled through adoption of good agronomic practices. For instance, it has been suggested that sowing sesame in the first season (late April) on the onset of rainfall shows less infestation by webworm than sowing 2 and 4 weeks after onset (WAO) of rainfall. With applying insecticide twice at 2 and $4 \mathrm{WAO}$, they obtained yields of 1039,489 , and $264 \mathrm{~kg} \mathrm{ha}^{-1}$ for onset, $2 \mathrm{WAO}$, and $4 \mathrm{WAO}$, respectively (Egonyu et al., 2009a). Therefore, early planting of sesame is encouraged. Other pest management strategies could be through the use of tolerant or resistant varieties. It has been reported that some introduced new genotypes with hairy stems, leaves and capsule have resistances to the gall midge than those non-hairy cultivars (Ubor et al., 2015). Other management practices such as intercropping with finger millet have been found to control pests. For instance, it was reported that intercropping sesame with finger millet increased death of larvae of sesame webworm while increasing the number and types of its biological enemies (Egonyu et al., 2009b).

\subsubsection{Improvement in marketability of Ugandan sesame seeds and market chain}

Broadening market availability of sesame seeds in Uganda to gain international standards could improve sesame production in Uganda. Sesame farmers should be trained on how to ensure proper seed quality to compete favorably in the global sesame seed trade. Training of sesame farmers on how to handle sesame seeds and avoid adulteration with sand, and proper storage to reduce pests and fungal attacks such as Aspergillus growth during drying sesame should be taught to small holder farmers. In addition, pesticide residues are also contaminants that affect the sesame seed markets. Farmers should be advised not to allow contaminants to compromise the quality of sesame seeds. Sesame seed standards or export should be explained in simple terms to farmers so that they understand what to produce. Furthermore, reducing the number of middlemen in sesame seed trade could greatly improve the economic benefits to rural farmers. Usually the sesame seeds are bought from farmers at cheap farm gate prices, by the rural traders who sell to the wholesalers who in turn again sell to the domestic processors or exporters (Dalipagic and Elepu, 2014). In providing sesame markets to farmers, it is therefore important to reduce the number of middlemen in the marketing chain. There are several middlemen in the sesame markets, and these significantly reduce the benefits of sesame marketing to the producer farmers. In the sesame value chain, middlemen usually buy at prices lower than even the set farm gate prices of sesame since they are profit-oriented. It could be suggested that the number of local traders and rural retailers who form the main part of the middlemen be reduced so that sesame farmers can sell their seeds directly to exporters or wholesalers or process and sell to final domestic consumers at reasonable prices. 
Once middlemen are reduced, the sesame farmers could also make contracts with large urban companies through mutual agreements to have stronger markets with contractors signing profitable contracts with sesame farmers. For instance, a scenario where a sesame company provides inputs and training to farmers and then buys the sesame produced from the farmer would boost production. These sesame companies should also be linked to large sesame exporters in the world so that there is a readily available market for sesame. In the cases where companies are not readily available, the sesame farmers could also personally engage in processing after obtaining financial support from private and government partners for processing facilities. Usually, little processing of sesame happens in Uganda, as most commonly sesame is roasted and ground in to paste for foods such as smoked fish, or meat, paste dressing on bread and sesame seeds roasted, mixed with honey, sugar and rolled in to balls to be eaten as snacks (Munyua et al., 2013). It necessary to encourage farmers to learn cheap processing methods. For sesame farmers operating through cooperatives or organized farmer groups, acquisition of equipment for processing sesame seeds from the raw form, to hulled, sesame oil and other products would significantly reduce the postharvest losses. Moreover, value addition to sesame for local consumption would be readily applied to the produced seeds when international markets are not available.

\subsubsection{Awareness on the nutritional and health promoting benefits of sesame seeds}

Although sesame seeds are rich in nutrients, and promote better health, there is still need to increase popularizing sesame products in Ugandan diets. Research shows that there is increased hypertension among diabetic patients in Uganda that lead to development of cardiovascular complications and consequently death (Muddu et al., 2018). Research has also reported high prevalence of hypertension among Ugandan population (Guwatudde et al., 2015). Fortunately, sesame has been reported to control blood pressure in hypertensive patients (Sankar et al., 2005). For instance, a study on the effects of sesame oil on endothelial function has shown that it can increase flow-mediated dilation (FMD) in hypertensive patients (Karatzi et al., 2015). Karatzi et al. reported that sesame oil has both local and short acting benefits such as vasodilation thereby controlling hypertension. In another study, sesame oil mixed with sunflower oil in combination with nifedipine showed a significant decrease in blood pressure compared to nifedipine-only in patients with hypertension (Sudhakar et al., 2011).

On the other hand, the prevalence of diabetes mellitus is still low among Ugandans and could still be prevented with public awareness (Bahendeka et al., 2016). These diseases could be managed through adding sesame in the diet. Sesame and its lignans have beneficial effects in treatment of diabetes through reducing the blood glucose levels and decreasing the plasma total cholesterol. For instance, in a study to evaluate the effectiveness of sesame oil with anti-diabetic (glibenclamide) medication as combination therapy in type 2 diabetes mellitus patients, it was found out that glibenclamide in combination with sesame oil significantly enhanced anti-hyperglycemic efficacy as compared with their monotherapy (Sankar et al., 2011). Significant reductions in the plasma total cholesterol, low-density lipoprotein cholesterol and triglycerides levels were noted in sesame oil therapies attributed to the high content of poly and monounsaturated fatty acids in sesame oil that are also rich in lignans that improve lipid profile. Furthermore, in a study involving 46 participants with type 2 diabetes, it was reported that diabetic patients who ingested sesame oil had significantly lower level of glucose and higher insulin compared with patients in the control after 90 days (Aslam et al., 2018). Also at 90 days, glycated haemoglobin (HbA1c) was found to be significantly lower in those with sesame oil treatment than the control and the biomarkers of liver, cardiac, and renal functions were improved significantly in diabetic patients who ingested sesame oil. These beneficial effects of white sesame seed oil were attributed to the bioactive components from sesame seed oil, primarily the presence of monounsaturated fatty acids. Therefore, research has shown that including sesame oil blended with refined rice bran oil in daily cooking and its consumption is important especially for Diabetes mellitus patients lowering the hyperglycemia (Devarajan et al., 2016). These are attributed to higher polyunsaturated fatty acids such as linoleic and linolenic acids, abundant lignans such as sesamin and sesamolin that confer health benefits (Hwang, 2005; Wu, 2007). Additionally, sesame contains sesamol, a natural antioxidant which acts as cardioprotective agent (Asghar et al., 2014). The benefits arising from these antioxidants especially sesamol for cardiovascular diseases are attributed to recycled endogenous antioxidants including vitamin $\mathrm{E}$ that protect free radical lowdensity lipoprotein cholesterol oxidation and reduce the risk of cardiovascular disease (Jayaraj et al., 2020). Uganda produces abundant white sesame, and it is also known that sesame cultivars with white seed coats usually contain higher sesamin and sesamolin including sesamol contents than black sesame (Wang et al., 2013). Hence, inclusion of sesame in the diet could improve health.

Furthermore, plant oils such as peanut, soybean, avocado, including sesame have anti-inflammatory effects relieving joint pains and typically have been applied in massage usages. The oils also protects the skin from UV radiation thus being extensively used in cosmetic industries, and in used as antimicrobial agents, anti-carcinogenic properties and hence are important in dermatological care as well as other skin care products (Lin et al., 2018). Other findings suggest that sesame seeds when included in the diet could improve blood lipids, and sex hormones benefiting postmenopausal women ( $\mathrm{Wu}$ et al., 2006). All these suggest sesame paste, oil and all other products confer health promoting benefits and awareness of the consumers should be promoted to trigger increased domestic production of sesame seeds upon creating its demand in Uganda. Creating awareness on health benefits could also enable investors establish industries processing sesame seeds to health, nutritional and cosmetic products that would increase demand for sesame seeds enhancing farmers' production.

\subsubsection{Strengthening sesame seed producer farmers groups, associations and cooperatives}

Although there are several farmers producing sesame seeds in Uganda both individually and in groups, there is still more need to create stronger groups emphasizing production of oilseed crops. Farmer associations and cooperatives in the 


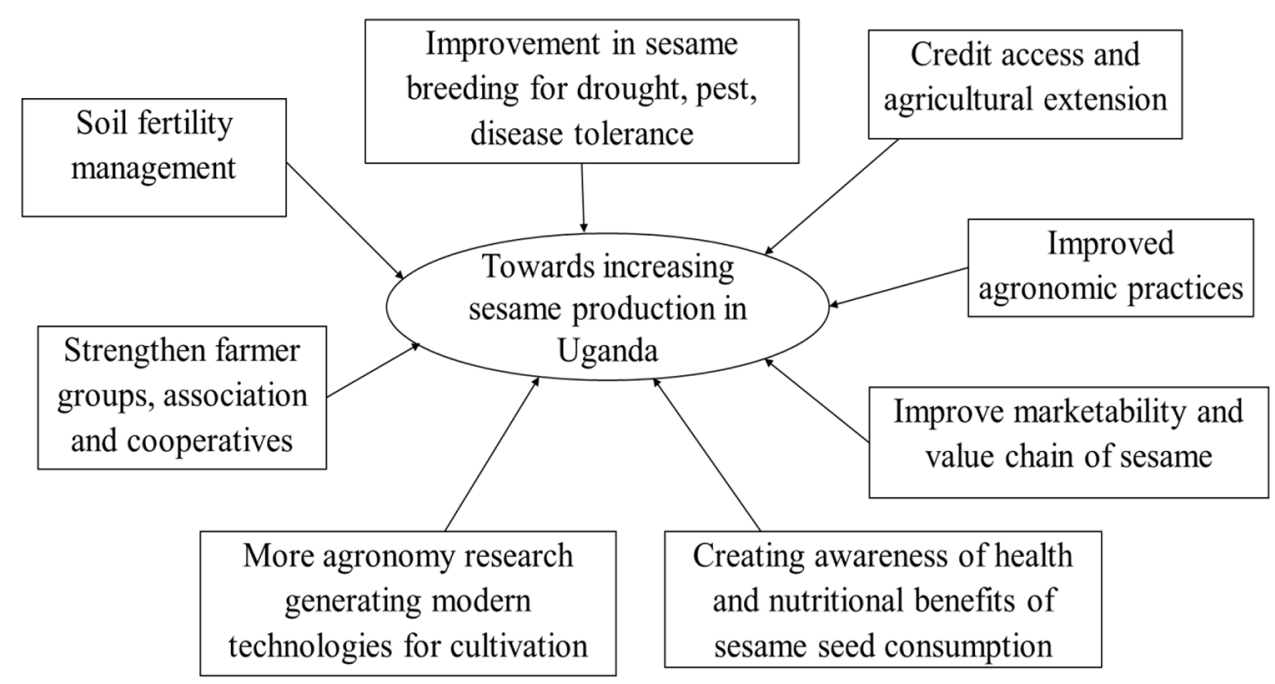

Fig. 7. Summary of suggested strategies to increase sesame seed production and trade in Uganda.

West Nile and Eastern regions of Uganda have greatly boosted oilseed production providing bulking and collective marketing in addition to capacity building (Vorley et al., 2015). Furthermore, farmer cooperatives of oilseed crops have access to effective community-based extension services to help individual farmers with agricultural services such as loans, market information, agronomic skills (Opio, 2012). Therefore, more groups should be formed and strengthened where there are emerging sesame farmers, and larger cooperatives where these are non-existent could be created to improve farmers' working environment to boost production since organized groups have capacity to produce sesame in bulk, and it is easier for companies to work with groups than individuals. To successfully achieve this, the government of Uganda should help promote sesame production and ensure its trade flourishes because it brings foreign currencies to the country.

\subsubsection{Need for more research on sesame agronomic technologies}

There has been limited research on sesame evidenced by low yield in most growing areas hence hampering its adoption and expansion in the world (Dossa et al., 2017). In Uganda, previous researches focused mainly on breeding new improved varieties with high yield (Sehr et al., 2016; Okello-Anyanga et al., 2016, 2017). Limited attention has been given to improving farmers' cultivation practices despite the need to shift from traditional subsistence to semi or fully commercialized farming systems. Usually high yielding varieties perform better on research stations than on farmers' fields due to differences in management. Researchers could bridge this gap by breeding under current farmer practices, starting with selections from farmer fields. Traditional breeding methods should include genotype selection from the farmers' fields to mitigate natural selection in which some sesame varieties perform well in an environment while others totally fail under harsh field conditions. In addition, the yield gap could be bridged by generating new findings on viable agronomic practices to replace outdated farmer practices so that farmers maximize the yield potential of newly bred sesame varieties.
Unfortunately, there is scarcity of research on good agronomic practices of sesame including mechanization, irrigation, soil management, pests and disease control incorporating advanced techniques in sesame production. Therefore, more research is still needed to understand sesame agronomic practices since modern agriculture requires new technologies that evolve from time to time.

\subsection{Summary of strategies to improve production}

Overall, no single solution completely solves the production challenges, but a combination of strategies accompanied by continuous research could increase and sustain sesame production in Uganda addressing number of challenges through suggested strategies (Fig. 7).

\section{Conclusions}

From this review, the Uganda sesame seed production significantly decreased between 2008 and 2018. There was also a drastic decline in the area harvested in 2008 compared to 2007 which contributed to the low production of sesame seed whereas the export quantity and values were significantly low in 1997-2003. Therefore, there is a decreasing trend in sesame production although Uganda was once among the top 10 producers of sesame seeds. Several factors such as pests and diseases, declining soil fertility status, drought, low yielding varieties, poor agronomic practices could be the major problems affecting production. However, among these challenges, production of sesame seeds by the farmer is the most important factor in increasing sesame production since socioeconomic and market related factors are secondary. Increasing sesame yield at farmer level will boost production because seed yield directly influences the quantity harvested. Sesame seed production could be increased through increasing area under cultivation while adopting proper agronomic practices. Therefore, there is need for intervention by farmers, policy makers, researchers and other stakeholders to increase sesame seed production. Future research should focus on how 
to increase seed yield on farmers' fields and bridge the yield gap between researchers an6d farmers while adopting good agronomic practices of sesame production in Uganda.

\section{Conflict of interest}

The authors declare that they have no conflicts of interest in relation to this article.

Acknowledgements. We thank the anonymous reviewers and editors for their valuable comments.

\section{References}

AfrII. 2017. Stabilizing sesame yields and production in the Lango region. Africa Innovations Institute, Project Fact Sheet.

AGRA. 2017. Africa Agriculture Status Report: The Business of Smallholder Agriculture in Sub-Saharan Africa (Issue 5). Nairobi, Kenya: Alliance for a Green Revolution in Africa (AGRA).

Anguria P, Chemining'wa GN, Onwonga RN, Ugen MA. 2017. Effect of Organic Manures on Nutrient Uptake and Seed Quality of Sesame. J Agric Sci 9(7): 135-144.

Anilakumar KR, Pal A, Khanum F, Bawas AS. 2010. Nutritional, medicinal and industrial uses of sesame (Sesamum indicum L.) seeds. Agric Conspec Sci 75(4): 159-168.

Anyanga WO, Obong YY. 2001. Sesame (Sesamum indicum L.). In: Mukiibi JK, ed. Agriculture in Uganda 11: 97-102.

Anyanga WO, Obong Y, Busolo-Bulafu CM, et al. 2003. A decade of sesame breeding in Uganda (1991-2000). UJAS 8: 135-140.

Anyanga OW, Rubaihayo P, Gibson P, Okori P. 2016. Combining ability and gene action in sesame (Sesamum indicum L) elite genotypes by diallel mating design. J Plant Breed Crop Sci 8: 250-256.

Asghar A, Majeed MN, Akhtar MN. 2014. A review on the utilization of sesame as a functional food. Am J Food Nutr 4(1): 21-34.

Ashri A. 1989. Sesame. In: Robbelen G, Downey RK, Ashri A, eds. Oil Crops of the World. New York: McGraw-Hill, pp. 375-387.

Aslam F, Iqbal S, Nasir M, Anjum AA. 2018. White Sesame Seed Oil Mitigates Blood Glucose Level, Reduces Oxidative Stress, and Improves Biomarkers of Hepatic and Renal Function in Participants with Type 2 Diabetes Mellitus. J Am Coll Nutr 0: $1-12$.

Bahendeka S, Wesonga R, Mutungi G, Muwonge J, Neema S, Guwatudde D. 2016. Prevalence and correlates of diabetes mellitus in Uganda: A population-based national survey. Trop Med Int Heal 21(3): 405-416. https://doi.org/10.1111/tmi.12663.

Bayoumi T, El-Bramawy MA. 2007. Genetic analyses of some quantitative characters and Fusarium wilt disease resistance in sesame. Afr Crop Sci Conf Proc 8: 2198-2204.

Bedigian D. 2003a. Evolution of sesame Revisited: Domestication, diversity and prospects. Genet Resour Crop Ev 50: 799-787.

Bedigian D. 2003b. Sesame in Africa: Origin and Dispersals. In: Neumann K,Butler A, Kahlheber S, eds. Food, Fuel and Fields: Progress in African Archaeobotany. Cologne: Heinrich Bert Institute, pp. 17-36.

Bedigian D. 2010. Cultivated sesame and wild relatives in the genus Sesamum L. In: Bedigian D, ed. Sesame: the genus Sesamum. CRC Press, Taylor \& Francis Group, pp. 33-77.

Boureima S, Eyletters M, Diouf M, Diop TA, Van Damme P. 2011. Sensitivity of seed germination and seedling radicle growth to drought stress in sesame (Sesamum indicum L.). Res J Environ Sci 5(6): 557-564.
Boureima S, Oukarroum A, Diouf M, Cisse N, Van Damme P. 2012. Screening for drought tolerance in mutant germplasm of sesame (Sesamum indicum) probing by chlorophyll a inflorescence. Environ Exp Bot 81: 37-43.

Brigham RD. 1985. Status of sesame research and production in Texas and USA. In: Sesame and safflower status and potentials. Rome, Italy: FAO, pp. 73-74.

Couch A, Gloaguen RM, Langham DR, Hochmuth GJ, Bennett JM, Rowland DL. 2017. Non-dehiscent sesame (Sesamum indicum L.): Its unique production potential and expansion into the southeastern USA. J Crop Improv 72.

Dalipagic I, Elepu G. 2014. Agricultural value chain analysis in Northern Uganda: Maize, rice, groundnuts, sunflower and sesame. Action Against Hunger, ACF-International.

Devarajan S, Chatterjee B, Urata H, et al. 2016. A Blend of Sesame and Rice Bran Oils Lowers Hyperglycemia and Improves the Lipids. Am J Med 129: 731-739. https://doi.org/10.1016/j. amjmed.2016.02.044.

Dossa K, Diouf D, Wang L, et al. 2017. The Emerging Oilseed Crop Sesamum indicum Enters the "Omics" Era. Front Plant Sci 8: 116.

Egonyu JP, Kyamanywa S, Anyanga W, Ssekabembe CK. 2005. Review of pests and diseases of sesame in Uganda. Afr Crop Sci Conf Proc 7: 1411-1416.

Egonyu J, Kyamanywa S, Ssekabembe C. 2009a. Integration of time of planting and insecticide application schedule to control sesame webworm and gall midge in Uganda. J Appl Biosci 18: 967-975.

Egonyu J, Kyamanywa S, Ssekabembe C. 2009b. Natural enemies of sesame webworm and the effect of additive intercropping on its incidence in Uganda. J Appl Biosci 18: 1019-1025.

Elamin AEH, El Naim AM, Ali EA. 2015. Impact of the sesame seed bug (Elasmolomus sordidus) on damaging sesame seeds. Int $J$ Anim Biol 1(4): 106-109.

Epule TE, Ford JD, Lwasa S, Nabaasa B, Buyinza A. 2018. The determinants of crop yields in Uganda: what is the role of climatic and non-climatic factors? Agric Food Secur 7:10

FAOSTAT. 2018. Food and Agriculture of the United Nation Statistical database. http://www.fao.org/faostat/en/\#compare.

Fukuda Y, Osawa T, Namiki M. 1985. Studies on antioxidative substances in sesame seed. Agric Biol Chem 49(2): 301-306.

Gebrelibanos G. 2015. Growth, yield and yield component of sesame (Sesamum indicum L.) as affected by timing of nitrogen application. J Bio Agric Healthcare 5(5): 165-169.

Gore BBN, Akaza MJ, Kouassi NJ, Otte OGM, Akaffou DS, Zoro BIA. 2016. Effects of sawdust and poultry manure on growth and yield of sesame (Sesamum indicum L.). IJSEAS 2(11): 100-105.

Guwatudde D, Mutungi G, Wesonga R, et al. 2015. The epidemiology of hypertension in Uganda: Findings from the national noncommunicable diseases risk factor survey. PLoS One 10(9): 1-13. https://doi.org/10.1371/journal.pone.0138991.

Hafiz SI, El-Bramawy MAS. 2012. Response of sesame (Sesamum indicum L.) to phosphorus fertilization and spraying with potassium in newly reclaimed sandy soils. Int J Agric Sci Res 1(3): 034-040.

Haruna I. 2011. Dry matter partitioning and grain yield potential in sesame (Sesamum indicum L.) as influenced by poultry manure, nitrogen and phosphorus at Samaru, Nigeria. J Agric Technol 7 (6): 1571-1577.

Haruna IM, Abimiku MS. 2012a. Yield of Sesame (Sesamum indicum L.) as Influenced by Organic Fertilizers in the Southern Guinea Savanna of Nigeria. SAR 1(1): 66-69.

Haruna IM, Aliyu L. 2012b. Seed yield and economic returns of sesame (Sesamum indicum L.) as influenced by poultry manure, 
nitrogen and phosphorus fertilization at Samaru, Nigeria. Rev Cient UDO Agric 12(1): 152-156.

Hassan MAM. 2012. Studies on Egyptian sesame seeds (Sesamum indicum L.) and its products 1-Physicochemical analysis and phenolic acids of roasted Egyptian sesame seeds. World J Dairy Food Sci 7(2): 195-201.

Hwang LS. 2005. Sesame oil. In: Shahidi F, ed. Bailey's Industrial Oil and Fat Products, 6th ed. New York: John Wiley and Sons Inc., pp. 538-577.

Jadav DP, Padamani DR, Polara KB, Parmar KB, Babaria NB. 2010. Effect of different level of sulphur and potassium on growth, yield and yield attributes of sesame (Sesamum indicum L.). Asian J Soil Sci 5(1): 106-108.

Jayaraj P, Narasimhulu CA, Rajagopalan S, Parthasarathy S, Desikan R. 2020. Sesamol: A powerful functional food ingredient from sesame oil for cardioprotection. Food Funct.

Kamal-Eldin A, Appelqvist LA, Yousif G, Iskander GM. 1992. Seed lipids of Sesamum indicum and related wild species in Sudan. The sterols. J Sci Food Agric 59(3): 327-334.

Kanu PJ, Bahsoon JZ, Kanu JB, Kandeh JBA. 2010. Nutraceutical Importance of Sesame Seed and Oil. A Review of the Contribution of their Lignans. Sierra Leone J Biomed Res 2(1): 4-16.

Karatzi K, Stamatelopoulos K, Lykka M, et al. 2015. Sesame oil consumption exerts a beneficial effect on endothelial function in hypertensive men. Eur J Prev Cardiol 20(2): 202-208.

Kashani S, Buriro M, Nadeem A, et al. 2015. Response of Various Sesame Varieties under the Influence of Nitrogen and Phosphorus Doses. Am J Plant Sci 6: 405-412.

Langham DR. 2008. Growth and Development of Sesame. San Antonio, TX: American Sesame Grower Association, 44 p.

Langham DR. 2020. Sesame Agronomic and Administrative Descriptors, Part 2 (Sesamum indicum L.). Sesame Res, LLC, Texas, USA.

Lin TK, Zhong L, Santiago JL. 2018. Anti-inflammatory and skin barrier repair effects of topical application of some plant oils. Int J Mol Sci 19: 70. https://doi.org/10.3390/ijms19010070.

Lowder SK, Skoet J, Raney T. 2016. The Number, Size, and Distribution of Farms, Smallholder Farms, and Family Farms Worldwide. World Dev 87: 16-29. https://doi.org/10.1016/j. worlddev.2015.10.041

Matina GD, Anyanga W, Karungi JT, et al. 2016. Sources and inheritance of resistance to sesame webworm in Uganda. In: 5 th RUFORUM Biennial Regional Conference 14(2): 537-543.

Mian MAK, Uddin MK, Islam MR, Sultana NA, Kohinoor H. 2011. Crop performance and estimation of the effective level of phosphorous in sesame (Sesamum indicum L.). Acad J Plant Sci 4 (1): 01-05.

Muddu M, Mutebi E, Ssinabulya I, Kizito S, Mondo CK. 2018. Hypertension among newly diagnosed diabetic patients at Mulago national referral hospital in Uganda a cross sectional study. Cardiovasc J Afr 29: 218-224. https://doi.org/10.5830/CVJA2018-015.

Munyua B, Orr A, Okwadi J. 2013. Open Sesame: A value Chain Analysis of Sesame Marketing in Northern Uganda. International Crops Research Institute for the Semi-Arid Tropics, Socioeconomics Discussion Paper Series 6.

Musinguzi P, Ebanyat P, Tenywa JS, Basamba TA, Tenywa MM, Mubiru D. 2015. Precision of farmer-based fertility ratings and soil organic carbon for crop production on a Ferralsol. Solid Earth 6: 1063-1073.

Nagendra Prasad MN, Sanjay KR, Prasad DS, Vijay N, Kothari R, Swamy SN. 2012. A Review on Nutritional and Nutraceutical Properties of Sesame. J Nutr Food Sci 2(2): 127.
Nakyagaba NW, Ssekabembe CK, Osiru DSO. 2005. An overview of the agronomic constraints to simsim production in Uganda. Afr Crop Sci Soc Proc 7: 1221-1228.

Ndor E, Jayeoba O, Asadu C. 2015. Effect of biochar soil amendment on soil properties and yield of sesame varieties in Lafia, Nigeria. Am J Exp Agric 9: 1-8.

Nzikou JM, Matos L, Kalou GB, et al. 2009. Chemical Composition on the Seeds and Oil of Sesame (Sesamum indicum L.) Grown in Congo-Brazzaville. Adv J Food Sci Technol 1(1): 6-11.

Ogbonna PE, Umar-Shaba YG. 2012. Influence of poultry manure application on growth and yield performance of accessions of sesame (Sesamum indicum L.) in a derived savanna transition zone of South eastern Nigeria. Afr J Agric Res 7(30): 4223-4235.

Okello-Anyanga W, Rubaihayo P, Gibson G, Okori P. 2016. Genotype by environment interaction in sesame (Sesamum indicum L.) cultivars in Uganda. Afr J Plant Sci 10: 189-202. https://doi.org/ 10.5897/ajps2016.1426.

Okello-Anyanga W, Hansel-Hohl K, Burg A, et al. 2017. Towards the Selection of Superior Sesame Lines Based on Genetic and Phenotypic Characterisation for Uganda. J Agric Sci 9(9): 13. https://doi.org/10.5539/jas.v9n9p13.

Opio MA. 2012. Empowering Women in the Oilseeds Business: The Case of PKWI Women's Cooperative. SNV Netherlands Development Organization.

Paul SK, Khatun MM, Sarkar AR. 2019. Effect of sulphur on the seed yield and oil content of sesame (Sesamum indicum L.). J Bangladesh Agril Univ 17(1): 33-38.

Raza MA, Feng LY, Manaf A, et al. 2018. Sulphur application increases seed yield and oil content in sesame seeds under rainfed conditions. F Crop Res 218: 51-58.

Rubaihayo PR, Anyanga OW. 1997. Genetic variation and interrelations among characters of sesame. Afr Crop Sci Conf Proc 3(1): 175-181.

Sani I, Okpalaoka CC, Bello F, Warra AA, Abdulhamid A. 2014. Flavonoid content and antioxidant potential of white and brown sesame seed oils. Eur J Biomed Pharm 1(3): 56-63.

Sankar D, Sambandam G, Rao MR, Pugalendi KV. 2005. Modulation of blood pressure, lipid profiles and redox status in hypertensive patients taking different edible oils. Clin Chim Acta 355: 97-104.

Sankar D, Ali A, Sambandam G, Rao R. 2011. Sesame oil exhibits synergistic effect with anti-diabetic medication in patients with type 2 diabetes mellitus. Clin Nutr 30: 351-358.

Scherer HW. 2001. Sulphur in crop production-invited paper. Eur $J$ Agron 14: 81-111.

Sehr EM, Okello-Anyanga W, Hasel-Hohl K, et al. 2016. Assessment of genetic diversity amongst Ugandan sesame (Sesamum indicum L.) landraces based on agromorphological traits and genetic markers. J Crop Sci Biotechnol 19(1): 117-129. https://doi.org/ 10.1007/s12892-015-0105-x.

Shehu HE. 2014. Uptake and agronomic efficiencies of nitrogen, phosphorous and potassium in sesame (Sesamum indicum L.). Am $J$ Plant Nutr Fertil Technol 4: 41-56.

Shehu HE, Kwari JD, Sandabe MK. 2009. Nitrogen, phosphorous and potassium nutrition of sesame (Sesamum indicum) in Mubi, Nigeria. Res J Agron 3: 32-36.

Sibhatu KT, Qaim M. 2017. Rural food security, subsistence agriculture, and seasonality. PLoS One 12(10): 1-15. https:// doi.org/10.1371/journal.pone.0186406.

Sohi S, Krull E, Lopez-Capel E, Bol R, Ziolkowski A. 2010. A review of biochar and its use and function in soil. Adv Agron 105: 47-82.

Ssekabembe CK. 2007. Comparison of research on sesame (Sesamum indicum L.) and nakati (Solanum aethiopicum) at Makerere University. Afr Crop Sci Conf Proc 63: 2063-2069. 
Ssekabembe CK, Okidi J, Ogenga-Latigo MW, Nabasrye M. 2006. Occurrence and species range of insect pests of simsim in northern and eastern Uganda. MURJ 1: 25-35.

Sudhakar B, Kalaiarasi P, Al-Numair KS, Chandramohan G, Rao RK, Pugalendi KV. 2011. Effect of combination of edible oils on blood pressure, lipid profile, lipid peroxidative markers, antioxidant status, and electrolytes in patients with hypertension on nifedipine treatment. Saudi Med J 32(4):379-385.

Ubor W, Gibson P, Anyanga W, Rubaihayo P. 2015. Inheritance of resistance to sesame gall midge in Uganda. Afr Crop Sci 23:355-363.

UBOS. 2014. Uganda Bureau of Statistics. Population Projections 2015-2020.

UBOS. 2016. Uganda Bureau of Statistics. National Population and Housing Census Report.

Umar K, Biruma G, Anyanga W, Alepo B. 2020. How to grow sesame, "The white Gold". National Semi-Arid Resources Research Institute (NaSARRI)/Africa Innovations Institute (AfrII)/Uganda Oil Seed Producers Association (UOSPA)/Farm input Care Center Ltd (FICA).

Unal MK, Yalcin H. 2008. Proximate composition of Turkish sesame seeds and characterization of their oils. Grasas Aceites 59(1): 23-26.

Uzun, B, Arslan C, Furat S. 2008. Variation in fatty acid composition, oil content and oil yield in a germplasm collection of sesame (Sesamum indicum L.). J Am Oil Chem Soc 85: 1135-1142.

Vorley W, Els L, Mubiru S, et al. 2015. Growing inclusion? Insights from value chain development in Ugandan oilseeds. London: International Institute for Environment and Development (IIED).
Wacal C, Ogata N, Basalirwa D, et al. 2019a. Growth, Seed Yield, Mineral nutrients and Soil Chemical Properties of Sesame (Sesamum indicum L.) as influenced by Biochar Addition on Upland Fields Converted From Paddy. Agronomy 9(2): 55. https:// doi.org/10.3390/agronomy9020055.

Wacal C, Ogata N, Basalirwa D, et al. 2019b. Imbalanced Soil Chemical Properties and Mineral Nutrition in Relation to Growth and Yield Decline of Sesame on Different Continuously Cropped Upland Fields Converted Paddy. Agronomy 9(4): 184. https://doi. org/10.3390/agronomy9040184.

Wang L, Zhang Y, Li P, et al. 2013. Variation of sesamin and sesamolin contents in sesame cultivars from China. PakJ Bot 45: 177-182.

Wei X, Liu K, Zhang Y, et al. 2015. Genetic discovery for oil production and quality in sesame. Nat Commun 6: 1-10.

$\mathrm{Wu}$ WH. 2007. The contents of lignans in commercial sesame oils of Taiwan and their changes during heating. Food Chem 104: 341-344.

Wu WH, Kang YP, Wang NH, Jou HJ, Wang TA. 2006. Sesame ingestion affects sex hormones, antioxidant status, and blood lipids in postmenopausal women. J Nutr 136: 1270-1275.

Zahran HA, Abd-Elsaber A, Tawfeuk HZ. 2020. Genetic diversity, chemical composition and oil characteristics of six sesame genotypes. OCL 27: 39.

Zenawi G, Mizan A. 2019. Effect of Nitrogen Fertilization on the Growth and Seed Yield of Sesame (Sesamum indicum L.). Int $J$ Agro Article ID 5027254, 7.

Cite this article as: Wacal C, Basalirwa D, Okello-Anyanga W, Murongo MF, Namirembe C, Malingumu R. 2021. Analysis of sesame seed production and export trends; challenges and strategies towards increasing production in Uganda. Uganda. OCL 28: 4. 